Revista Iberoamericana, Vol. LXX, Núms. 208-209, Julio-Diciembre 2004, 697-720

\title{
LA CREACIÓN DE LA NACIÓN PERUANA EN LAS REVISTAS CULTURALES DEL CUSCO (1910-1930)
}

\author{
POR \\ YAZMín LÓPEZ LENCI \\ Freie Universität Berlin
}

Entre 1910 y 1930 la historia literaria y cultural peruana atraviesa un proceso de transformación radical, cuya complejidad y disimilitud es accesible a partir de una observación detenida de las revistas culturales que se publican en diferentes regiones del país. Las pequeñas iniciativas periodísticas inauguran nuevos espacios de disputa cultural e ideológica, promocionan el ascenso de una multiplicidad de nuevos sujetos productores dentro del ámbito de la cultura letrada, pero sobre todo, patrocinan una explosión de narrativas sobre la nación. ${ }^{1}$ Este último aspecto ocupa una posición preferencial en el área surandina del Perú, en la que diversos grupos emergentes de escritores e intelectuales unificaron su discurso en una estrategia de enfrentamiento a las prácticas discursivas hegemónicas, pero que se diversificaron de acuerdo a diferentes intereses. Estos grupos sedimentaron su articulación como factores de una nueva cultura peruana al desarrollar la relación entre nación y originalidad del pensamiento andino, operación que determina el desplazamiento de la autoridad del debate cultural, cuyo espacio se concentraba en la capital de Lima, a la región de los Andes.

Dentro de este proceso el espacio cusqueño va a adquirir una trascendencia definitoria, hasta ahora no suficientemente evaluada, que se manifestará en una intensa actividad periodística y ensayística tanto dentro del área académica como fuera de ella. La Reforma de 1909 en la Universidad San Antonio Abad del Cusco operó como articulador de iniciativas editoriales de estudiantes, profesores y periodistas en la primera tentativa cusqueña en el siglo xx de producir un discurso regional. La revista La Sierra, como el órgano de difusión de la Reforma Universitaria, editada en los talleres del periódico El Sol y dirigida por el periodista José Angel Escalante, se propuso combinar la propaganda con el interés científico a fin de quebrar el aislamiento intelectual y de propiciar la discusión y difusión de los problemas regionales. Por otro lado, pretendió la cohesión intelectual de la generación emergente cusqueña, acudiendo al prestigio del pasado.

La Revista Universitaria, fundada por el joven rector norteamericano Albert Giesecke (nombrado por el gobierno central después de los sucesos de la Reforma de 1909) y por los jóvenes cusqueños del grupo La Sierra, se publicó a partir de 1912 como el "Órgano

\footnotetext{
${ }^{1}$ He desarrollado el papel fundacional de las revistas culturales peruanas de este período y las relaciones con el proceso vanguardista literario en El laboratorio de la vanguardia literaria en el Perú.
} 
de la Universidad del Cusco", aunque también albergó a miembros del antiguo Centro Científico del $\mathrm{Cuzco}^{2}{ }^{2}$ La revista se propuso abordar científicamente la realidad de la región del Cusco bajo diferentes disciplinas, aunque concentró sus esfuerzos en redimensionar los estudios históricos. A través de sus páginas se difundieron investigaciones de alumnos, graduados y docentes sobre folclore, literatura y música quechuas, monografías etnográficas que describían prácticas religiosas, fiestas, alimentación y vestimentas de las comunidades campesinas; pero sobre todo, trabajos acerca de la organización laboral y el régimen de propiedad de las mismas. Los jóvenes abogados cusqueños Luis E. Valcárcel y Félix Cosio, protagonistas de la Reforma, revalorizaron la organización comunal y plantearon la necesidad de legalizar el régimen de propiedad colectiva para impedir las crecientes usurpaciones de tierras practicadas por los terratenientes de la región. La preocupación jurídica se extiende a la necesidad, según los jóvenes abogados, de reglamentar la aplicación de justicia en los casos de criminalidad indígena y de levantamientos campesinos, para lo cual proponen que se dicte un código especial para las sublevaciones, la conducción bilingüe de los juicios y la presencia de jueces con "altas calidades morales”. La preocupación por el desarrollo industrial y la producción agrícola de la región llevaría a proponer un modelo de modernización liberal que contemplara la reforma del régimen de propiedad de la tierra, la división de los grandes latifundios, la enajenación de los bienes rústicos de la Iglesia, el cultivo intensivo, la introducción de nuevos cultivos, y el uso de maquinaria (Valcárcel “La cuestión...”), así como la construcción de vías de comunicación, el fomento de la inmigración y llegada de capitales, la creación de nuevas necesidades de consumo y la instrucción de los campesinos (Giesecke).

El grupo que editó La Sierra y apoyó la iniciativa de la Revista Universitaria estuvo integrado por Luis E. Valcárcel, Félix Cosio, José Uriel García, Rafael Aguilar, Miguel Corazao, Humberto Luna, Francisco Tamayo, José Mendizábal y Luis Rafael Casanova, quienes se presentaron a sí mismos como la encarnación del potencial intelectual del Cusco y como los sujetos renovadores del periodismo y de las relaciones de fuerza dentro del campo intelectual. Para ello propusieron la cohesión de la élite intelectual cusqueña a través de una campaña que dotara de prestigio al pasado, de la vulgarización del debate científico reservado a la élite, y del tratamiento de tópicos regionales (véase La Sierra 1 1910). El empeño historicista cusqueño está vinculado al proyecto historiográfico que José de la Riva Agüero había lanzado en 1910, alentando la constitución de la nacionalidad a partir de la integración del período colonial y del imperio incaico en los estudios históricos. Para el maestro limeño, que mantenía contacto con los intelectuales cusqueños a partir de los sucesos de la Reforma, la modernidad nacional se sustenta en la reconciliación con el pasado colonial. La respuesta cusqueña se expresaría rápidamente en una traslación

\footnotetext{
2 El Centro Científico del Cuzco (1897-1907) divulgó el proyecto de desarrollo de la élite terrateniente que se vio amenazada por el creciente poder económico de las recién instaladas sucursales de casas comerciales extranjeras. Nace hacia 1890 una conciencia de defensa de la economía local, que discute las posibilidades de explotación racional de las riquezas naturales y de la colonización de la selva, en una serie de estudios sobre geografía regional que publicó la revista del Centro. Véase Rénique, "El Centro...”.
} 
del eje y el objetivo de los estudios: no se trataba solamente de la recuperación del Cusco colonial y del Cusco imperial incaico, sino sobre todo, de posibilitar el resurgimiento del pensamiento andino. La estrategia cusqueña se amparó en los esfuerzos por demostrar, primero, que no se estaba rezagado respecto al movimiento científico contemporáneo, y segundo, la utilidad de la aplicación de los estudios académicos a la realidad.

Implementar este programa significaba fomentar el desarrollo de la historia, la arqueología, la etnografía, la sociología peruana y el folclore como disciplinas prioritarias. La respuesta cusqueña guarda una importante relación con el impacto que causó en el medio regional la llegada de las expediciones de científicos norteamericanos de la Universidad de Yale, encabezadas por Hiram Bingham entre 1911 y 1915. Los viajes de las expediciones interdisciplinarias extranjeras a Machu Picchu tuvo el efecto del agente externo que comunicó dos espacios geográficos lejanos y provocó interrogantes sobre el curso de la modernización regional andina.

A nivel institucional apreciamos consecuencias de este encuentro con los científicos norteamericanos a partir de la fundación en 1913 del Instituto Histórico del Cusco, que reunía a miembros de dos generaciones cusqueñas (el grupo de La Sierra y del Centro Científico del Cuzco), pero que sería presidido por el joven Valcárcel. Órgano del Instituto sería la revista Nuestra Historia de la cual solo pudo editarse un número, dedicado al rescate de la revolución de Pumacahua de 1814 y de un olvidado prócer cusqueño de la Emancipación. Con la fundación en 1916 del Centro Nacional de Arte e Historia, editor de la revista de literatura y arte Estudios, nos encontramos frente a un proyecto de la generación más joven integrada por los hermanos Cosio, Luis E. Valcárcel, Uriel García y Rafael Aguilar. El rescate del regionalismo del arte en el Perú fue el programa de esta institución, que aspiró a redefinir el carácter de la literatura nacional. La redacción de la revista denunció la ausencia absoluta de temas locales en la literatura peruana, demandando "un mayor esfuerzo para desprenderse del gusto fácil de la imitación, si no calco, de modelos exóticos” (Estudios 1, 1917). Los cusqueños concentraron significativos ensayos en desarrollar la tesis del carácter histórico del arte (el arte revela el "alma de su época”) atribuyéndole la potencialidad de reconstruir y de revivir sociedades desaparecidas. Dentro de esta articulación entre arte e historia, la cerámica, la arquitectura, la textilería, las tumbas y los cantares populares, serían entendidos y estudiados en este momento como los caracteres buscados del libro de la historia andina. Los miembros de la "Escuela Cusqueña”, nombre dado por Francisco García Calderón a la generación de la Reforma de 1909, anunciaron la traducción y la separación de la inintelegibilidad del gran macro-texto histórico andino, a fin de reconstruir la vida cotidiana y la sensibilidad colectiva del hombre andino antiguo.

Observamos pues que la década de 1910 en la ciudad del Cusco estuvo marcada por un proceso de ampliación de las fronteras intelectuales, que dependió del paulatino asentamiento de intereses comunes ligados no solo al proyecto de modernización económica liberal, sino a la articulación de un imaginario sustentador de un nuevo sistema cultural. La llegada del nuevo rector Giesecke coincidió con la maduración de pulsiones imaginarias de los grupos emergentes regionales del Cusco, que retomarían el incaísmo nativista como eje de discursos para la reconstrucción del sistema cultural peruano. Dentro de este proceso el debate sobre el rol de las universidades de provincias, y especialmente 
el de la Universidad del Cusco, ocupó una posición determinante en tanto respuesta al proyecto limeño de exclusión de las élites regionales. El proyecto de eliminación de las Universidades Menores (regionales) del Dr. Deustua, de Manuel Vicente Villarán (“Las profesiones liberales”) y de Luis Miró Quesada (“Diario de los debates”), cuyo objetivo era la centralización de la educación universitaria, ocuparía varios números de la Revista Universitaria, que llegaría a elaborar un discurso sobre el regionalismo como formador de la "conciencia regional”, piedra angular en la constitución de la nación, discurso que al mismo tiempo se articulaba como estrategia de enfrentamiento a la exclusión operada desde la capital de la república. ${ }^{3}$ Este regionalismo elaborado en los claustros académicos fue propuesto sobre cuatro líneas temáticas: el fomento del estudio de los problemas regionales, la afirmación de la originalidad de la cultura de cada localidad, la defensa de los intereses locales sin anteponerlos a los intereses nacionales y el patrocinio del progreso de las respectivas regiones (Ugarte 13-15). A lo largo de la la década de 1910 los intelectuales cusqueños se dedicaron a la sistematización del regionalismo, buscando su justificación en la historia, la naturaleza y las ciencias sociales, para lo cual se empeñaron en recoger hechos característicos de la región, clasificarlos teniendo en cuenta lo permenente a lo largo de la historia, explicar las diferencias regionales, fijar los límites de la regionalidad a la extensión de una zona convergente en un núcleo histórico que unificara intereses y aspiraciones, así como en sugerir los medios de aprovechamiento de tales peculiaridades regionales. Todo este esfuerzo estaba orientado a invertir la estrategia discursiva centralista y a predecir una futura dirección cultural de la nación en manos de la ciudad del Cusco, en la medida en que ésta reconoce la pluralidad de centros históricos, cultiva las ciencias y estudia a través de ellas su propio espacio regional. El presupuesto fue la existencia de las regiones en la amplia unidad de la nación, lo cual significaba rescatar las posibilidades de las instituciones académicas tradicionales del Cusco, Arequipa y Trujillo, y sobre todo de sus respectivas regiones. Bajo tal perspectiva, estas líneas de Félix Cosio condensan la primera propuesta de recartografía cultural que elaboró la élite cusqueña, la primera a su vez del siglo xx en el Perú:

I cuando esta Universidad se halla en estas condiciones, cuando ha llevado i puede llevar en mayor escala esta labor esencialmente de cultura nacionalista i de adentramiento regional, se le quiere hoy restar algunos de sus atributos importantes $i$ alentar contra su vida, en nombre de una alta selección espiritual hecha en sólo un centro, cuya influencia no puede esparcirse ni relativamente en un país extenso i variado como el nuestro, que necesita, antes que la quintaesencia de sabios profundos o de especialistas reconcentrados en una urbe soberbia, modestos órganos del pensamiento distribuidos en los principales centros tradicionales, que estén en contacto inmediato con las necesidades de las

\footnotetext{
${ }^{3}$ Estas líneas de Deustua muestran la naturaleza de la disputa de las élites en la elaboración de un proyecto de nación peruana. La élite intelectual limeña lamenta la disparidad y se postula como directora natural de la homogenización: "La conciencia nacional no puede formarse si la gran diversidad de factores étnicos que por desgracia constituyen nuestra sociedad, no recibe una dirección de una clase educadora animada de idénticos propósitos y decidida a seguir las mismas vías, en virtud de una cultura superior común”. ( "El problema de la educación nacional”. Citado en Ugarte, 15).
} 
regiones e infundan a la masa gris de sus poblaciones el aliento de cultura que dignifique la vida i abra nuevos i amplios horizontes a las aspiraciones de la colectividad. (26)

Aunque la élite intelectual del Cusco aceptaba la existencia de una “cultura superior”, desplazó el liderazgo homogeneizador responsable de una institución académica convertida en “oficinas de preparación mecánica a los exámenes” y de extensión de certificados, títulos y diplomas. Por ello, si la articulación de un sistema educativo alternativo dentro de un nuevo sistema cultural suponía el descentramiento o multiplicación de centros, la élite cusqueña creó una propuesta de reforma de la universidad nacional que incluía la participación conjunta de ambos tipos de universidades, de la "Mayor" (capitalina) y de "las Menores”. La nueva institución debería cumplir tres objetivos: el científico, definido como la transmisión de los resultados de la labor científica extranjera y la formación de una "ciencia nacional” mediante el estudio del territorio, de las historias y de las instituciones del país; el profesional, que supondría la adaptación a las condiciones de la actividad económica del país y a las necesidades de cada región; y el educativo, por el cual se perseguía la formación de "hombres patriotas y cultos”, vale decir, de la élite directriz (Ugarte).

Pero en esta propuesta hay otras correlaciones que es necesario considerar. Muchos de los intelectuales, periodistas y catedráticos involucrados en este proceso de modernización cultural crearon correspondencias semánticas entre la institución académica y la ciudad del Cusco, dándole a aquélla el carácter de voz traductora y pregonera de las pulsiones históricas de ésta. El centro letrado de la ciudad se introdujo en la vida socio-cultural con la función autoatribuida de medium, como la voz y el eco de las voces "interiores y remotas”, lo que la llevaba a autodefinirse como el laboratorio donde se ensayaría la creación del "nacionalismo histórico". Para llegar a esta elaboración discursiva se parte de la tesis del mestizaje como problema nacional, en la medida en que no podría existir la nación peruana si la coexistencia en una misma individualidad de dos elementos étnicos (“voces”) siguía siendo inarmónica, desequilibrada y enfrentada. La invención del nacionalismo contendría la virtualidad de restaurar el equilibrio perdido desde la invasión española. La obra de estudio interdisciplinario desde la universidad cusqueña cumpliría así la función de medium del pasado y sería el laboratorio de la reconstrucción nacional. De ello se desprende el singular empeño en la investigación histórica de la tradición indígena y de la tradición colonial. ${ }^{4}$ La formación de la nación solo podía concebirse, según la propuesta cusqueña, a través de la reconciliación del impulso modernizador con esta doble tradición, tesis que explica la desconstrucción del proceso emancipador y de la independencia porque el desprecio absoluto de la tradición conllevaba, para los intelectuales de San Antonio Abad, la “desnaturalización” del propio ser nacional:

... que la tendencia innovadora, desde hace un siglo, proclamase la improvisación de nuevos factores i nuevas influencias para reconstituir la nacionalidad, como si ésta

\footnotetext{
${ }^{4}$ Debe tenerse en cuenta que la derrota peruana en la Guerra del Pacífico, que enfrentó al Perú, Chile y Bolivia entre 1879 y 1883, desencadenó en el país una profunda crisis económica, política y social. Para la élite oligárquica limeña la creación de una historia nacional se convirtió en uno de los objetivos reconstructivos prioritarios.
} 
pudiera ser súbita obra de voluntades efímeras, i no la lenta i compleja creación histórica, en que los elementos concurrentes de raza i cultura, han tenido que amalgamarse bajo la paciente i fuerte presión del medio americano i del tiempo, supremo fecundador de frutos sociales. (Cosío 7)

De manera que inventar la nación devino en la misión de reconstruir la historia, la que a su vez debía probar la continuidad de la existencia colectiva peruana, de una memoria común. En 1921, con motivo del centenario de la independencia, La Sierra, en su editorial del $n^{\circ} 6$, afirma la vinculación entre arte, ciencia y nacionalismo; y anuncia el paso del período de la investigación al de proyección social. Los nuevos maestros postulan la urgencia de la difusión del saber científico fuera del enclave académico, cuyo precedente ya habían sentado La Sierra, Nuestra Historia y Estudios, y la "progresiva modificación de éste (realidad) por el esfuerzo doctrinario y por la crítica de los sistemas puestos en práctica en las diferentes ramas de la organización social”. Me interesa destacar la conexión de arte y nación con la creación del discurso de la sugestión histórica, imaginando que una conciliación temporal entre la majestuosidad atribuida al pasado imperial y un porvenir supuestamente esperanzador tendría un efecto articulador de la nacionalidad. Esta construcción de la narrativa se fue asentando paulatinamente como necesidad en el imaginario de la generación de 1909, cuya élite se impuso una obra de reconstrucción que debería rescatar para sí el original núcleo de la patria existente desde antiguo. Pero la sociedad antigua que se privilegiaba era la del Tahuantinsuyo porque se la entendía como la época de mayor “civilización” en el Perú. La élite, por su parte, cuya “decencia” le garantizaba presentarse como poseedora de una alta cultura, se autojustificaba en su proceso de apropiación de la herencia de la aristocracia inca.

La obra de sugestión histórica fue vista como posible si se inyectaba vitalidad al material que ofrecían los descubrimientos y estudios arqueológicos, la filología quechua, la literatura oral y el folclore regional. Ya a comienzos de la década de 1920 eran prácticas habituales las excursiones a los sitios históricos, las expediciones para el descubrimiento de nuevos restos arqueológicos y las visitas frecuentes a los ya descubiertos. Pero también los estímulos del propio trabajo evocador, como el entusiasmo frente a la visión de los restos aqueológicos, el gozo de un descubrimiento o la "misteriosa comunión con el alma de esas cosas que parecen muertas", contribuían al cuidado de los datos históricos sorprendidos directamente en las fuentes de estudio, y a su incorporación al sistema de conocimientos.

La evocación estética fue integrada como núcleo de los estudios históricos y arqueológicos, prestando relevancia no solo a las obras de literatura quechua, sino sobre todo al abundante folclore de la región. Uno de los proyectos más ambiciosos de la generación de 1909 dentro de la reestructuración del sistema cultural peruano fue la pretensión de restaurar la literatura quechua a través del cultivo de dramas y comedias en aquella lengua, así como la reconstrucción de la música llamada "incaica”. La música andina sería elevada a la categoría de semiótica de la unidad nacional, porque se le atribuía la fuerza de unificar a los cusqueños en el sentimiento de posesión de una conciencia plena de continuidad histórica y de persistencia espiritual: 
La música incaica, [...] se ha propagado tanto, que, dignificados por la alta armonización los aires del folklore se oyen con tanta reverencia i delectación como si fueran la vibración de sagradas lenguas que nos hablaran de un reino perdido o de una tierra por conquistar. (énfasis mío)

Continuidad y persistencia de una nación por reinventar, reconquistar o recuperar podría ser la consigna de los sujetos emergentes en el campo intelectual cusqueño, envueltos en la misión de “educación histórica” de la población mediante la exhibición de piezas dramáticas y musicales. A la obra de arte se le atribuye la funcionalidad de introducir en la comunidad los datos más característicos del pasado remoto y glorioso de los incas, y de despertar en el público la curiosidad por conocerlo. Esta curiosidad se manifestó en los estudios de muchos jóvenes sobre la lengua quechua, los trajes, las costumbres y las creencias del mundo regional andino.

Pero en 1921 detectamos por primera vez en la Revista Universitaria una autocrítica de la producción académica y de las teorías de los pedagogos e historiadores de San Antonio Abad, por haber supuesto el carácter estático de la “clase indígena” y la supuesta necesidad de una tutela, y sobre todo, por su incapacidad de prever el "histórico conflicto nacional”. ¿Qué es lo que ha sucedido? ¿De qué "histórico conflicto” se trata? En 1921 irrumpe, para sorpresa del pequeño mundo urbano del Cusco, el movimiento milenarista cusqueño con el levantamiento de los pastores de Toccroyoc (altiplanicie de la provincia de Espinar), liderados por el ganadero Domingo Huarca. Aunque su participación respondía al reclamo de la libre comercialización de lana, los ganaderos y campesinos actuaron bajo la idea del renacimiento de la nación inca. ${ }^{5}$ En este mismo año los campesinos de San Felipe (Sicuani) desfilaron delante de "piedras sagradas" anunciando la llegada del Señor; se tomaron los alrededores de Sicuani; se publicó el manifiesto de "Los hijos de Cahuide": A los indios del Cusco en El Tiempo de Lima (17 de octubre de 1921); y ocurrió la sublevación de Langui y Layo dirigida por Luis Condori, quien optó por un enfrentamiento psicológico por medio de fogatas, gritos y danzas rituales. Pero uno de los movimientos de mayor alcance fue el de los colonos de la hacienda de Lauramarca en 1922, encabezada por Francisco Chilihuani, Mariano Colque y Miguel Quispe, bautizado este último como "El Inca del Tahuantinsuyo”. ${ }^{6}$ Este líder recorría los Andes anunciando la restauración del imperio, al mismo tiempo que acudía a las prácticas

\footnotetext{
${ }^{5}$ El levantamiento exigía que el pueblo fuera declarado capital de distrito y se oponía al dominio terrateniente. Durante semanas las autoridades perdieron el control de la región, sin embargo sería fácilmente recuperado: “un jueves, día de mercado en Toccroyoc donde se reúnen los miembros de los diversos caseríos que constituyen la comunidad, aparecen hombres armados y a caballo de Yauri [...] se entabla la batalla, desigual en perjuicio de los campesinos, a pie y solamente provistos de hondas y armas improvisadas. En el curso del combate, según unos, cuando intenta huir y ocultarse disfrazado de mujer, según otros, el jefe de los rebeldes es herido, apresado y ejecutado. Su cuerpo quedará expuesto varios meses sobre el techo de la iglesia de Ocoruro para servir de lección a los vencidos” (Kapsoli, 69).

${ }^{6}$ El levantamiento de Lauramarca se extiendió a las haciendas de Palpa, Tocra, Ayuni y Laurayani. Con Miguel Quispe, que tiene su centro de operaciones en Paucartambo, alcanzó Colca, Quispicanchi, Espinar y Canchis.
} 
legalistas de tramitar ante el Patronato de la Raza Indígena del Cusco y de Lima acusaciones por usurpaciones de tierras. El "Inca” se enfrentó al indigenismo oficial, después de haber logrado entrevistarse con el propio presidente de la república Augusto B. Leguía y haber fracasado en sus trámites legales. El periódico cusqueño El Sol publicó una carta del "Inca” (19 de diciembre de 1922), en la que desenmascaraba el paternalismo de la estrategia oficialista: "Hablé con el presidente de la República, quien me obsequió cinco banderas diciéndome que amándolo y venerándolo sería respetado en mis derechos $i$ atendido en mis reclamos. Conservo las banderas y son las que llevo conmigo cuando me llego a las autoridades”.

Para muchos miembros de la élite cusqueña el movimiento del "Inca” no pretendía solamente recuperar tierras usurpadas. Estaban convencidos de que se trataba de una guerra étnica en pro de la restauración del Tawantinsuyu y de la imposición del culto al sol. La actividad de campesinos como Miguel Quispe, que llegaban hasta las capitales departamentales, e incluso hasta Lima, a difundir sus quejas, que se vinculaban con líderes anarco-sindicalistas, que tomaban contacto con la cultura urbana, y regresaban a sus comunidades para promover la resistencia violenta, provocó desconcierto y temor entre periodistas e intelectuales. En los siguientes fragmentos se aprecia cómo la élite ilustrada presenta a Quispe como líder y expresión de un fenómeno restaurador, y sobre todo, dan cuenta de la inversión del discurso indigenista oficial a favor de un discurso andino tradicional:

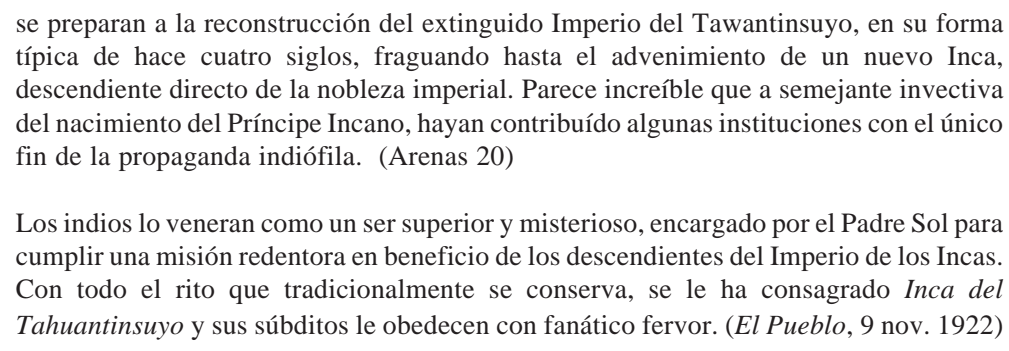
típica de hace cuatro siglos, fraguando hasta el advenimiento de un nuevo Inca, descendiente directo de la nobleza imperial. Parece increíble que a semejante invectiva del nacimiento del Príncipe Incano, hayan contribuído algunas instituciones con el único fin de la propaganda indiófila. (Arenas 20)

Los indios lo veneran como un ser superior y misterioso, encargado por el Padre Sol para cumplir una misión redentora en beneficio de los descendientes del Imperio de los Incas. Con todo el rito que tradicionalmente se conserva, se le ha consagrado Inca del Tahuantinsuyo y sus súbditos le obedecen con fanático fervor. (El Pueblo, 9 nov. 1922)

El desconcierto se transformó en los terratenientes cusqueños en una reacción crítica frente al leguiísmo y su política indigenista que, desde su perspectiva, lejos de proteger sus intereses económicos fomentaba la rebeldía campesina. Por su parte, el intelectual cusqueño Luis Felipe Aguilar, secretario de la Junta Departamental del Cusco del Patronato de la Raza Indígena, hizo público el desconcierto en el ámbito urbano cusqueño, y aunque reconocía la legitimidad de algunas reivindicaciones campesinas, criticó duramente a los supuestos instigadores de las rebeliones calificándolos de "falsos redentores de la raza”. Aguilar atacó especialmente a los líderes del Comité Tahuantinsuyo como Miguel Quispe, a quien denominó “embaucador” por haber fomentado la idea de "la restauración del Imperio Incaico, de cuya historia no tienen ni idea”; por incitar a la apropiación de tierras de las “que se imaginan haber sido despojados en algún tiempo”, y por tener "autoridades propias y regirse por sus propias leyes” (49, citado en Rénique “De la fe...”, 26). Aunque Luis Felipe Aguilar es uno de los pocos intelectuales que en el 
período de las insurrecciones indígenas tomó una actitud concreta frente a la inmovilidad de la llamada "Escuela Cusqueña", su posicionamiento apuntaba a respaldar una política estatal proteccionista en la que abogados como él debían asumir el liderazgo frente a los "arzobispos, médicos, ingenieros, literatos y personas de oropeles y campanillas que apenas conocen al indio por los fotograbados de los periódicos”. Por su parte, Félix Cosio descalificó a los comités obreros y pro-indígenas que propiciaban un acercamiento a los movimientos campesinos, acusándolos de apoyar un "falso indigenismo" y de buscar contribuciones para financiar las campañas de "propaganda socialista" en la capital del país. Así advertía el joven profesor Cosio a los maestros y estudiantes la naturaleza alarmante de un inminente conflicto social de gran envergadura, y exigía la pronta organización de un Patronato Indígena dentro de la universidad para operar como intermediario ante los órganos administrativos estatales:

\begin{abstract}
... si no se hace desaparecer en forma radical i rápida las causas que han herido de desesperación a los indígenas, el levantamiento de éstos tendrá todo el rojo resplandor de un fuego destructor i purificador, que anulará los actuales valores jurídicos de la propiedad territorial, i la rehará sobre las bases de un colectivismo ayllal; es decir reaparecerá la propiedad del ayllu i aun la constitución social de estos núcleos en su pureza primitiva, aunque adaptado, en cuanto al aprovechamiento de la tierra, a las formas nuevas del cultivo intenso con el auxilio de las máquinas i de la división del trabajo. ("La universidad” 58)
\end{abstract}

Las rebeliones campesinas indígenas que conmocionaron el sur andino entre 1919 y 1923 con su violencia defensiva, sus exigencias legales y su plataforma milenarista, enfrentaron a los intelectuales cusqueños con una realidad hasta el momento encubierta y relativamente distante. El proyecto modernizador que suscribían había supuesto la crítica al atraso económico, la falta de tecnificación y el carácter conservador de las haciendas y propietarios cusqueños. Sin embargo, cuando la realidad de las rebeliones ocupó la ciudad del Cusco a través de la presencia constante de líderes campesinos que presentaban denuncias ante el Patronato, tuvieron que tomar cuenta de la verdadera naturaleza del gamonalismo imperante en el campo de todo el departamento. Su propio proyecto “nacionalista” y “progresista” de construir una nación moderna fue cuestionado por las implicancias de la constitución del latifundio. Es conveniente subrayar que hasta 1920, como bien lo apunta Rénique, estos intelectuales se incluían como parte de la generación de intelectuales “oligárquicos”, integrantes de los partidos Civil, Liberal y Demócrata, al lado de José de la Riva Agüero, Víctor Andrés Beláunde, Javier Prado, Manuel Vicente Villarán y Juan Baustista de Lavalle (Rénique, “De la fe...” 28).

Sin embargo ya hacia 1917 puede detectarse un acuerdo de cooperación entre la Sociedad de Artesanos ${ }^{7}$ y la Asociación Universitaria, que empezaba a distanciarse críticamente de la visión optimista modernizadora de sus padres, y a desarrollar un

\footnotetext{
${ }^{7}$ La Sociedad de Artesanos fue fundada en 1870 con el objetivo de preparar a los artesanos en el proceso de modernización regional a partir del fomento del trabajo calificado y de los valores de la seriedad y diligencia. A mediados de la década de 1910 se constituyó en uno de los ejes de la dinámica urbana de la ciudad.
} 
cuestionamiento de la economía neo-colonial de la región. Aunque debe señalarse que este acercamiento no estuvo libre de contradicciones por las diversas posiciones que ambos grupos ocupaban dentro de la estructura social cusqueña. Los estudiantes de clase media ocupaban una posición estable y podían criticar el sistema del gamonalismo sin provocar serias reacciones. Si éstos difundían oralmente en asambleas la obra de González Prada, se consideraba revolucionaria, mientras si la misma salía de la boca de un artesano, por su posición frágil en el estrato medio, se la calificaba de subversiva. ${ }^{8}$

Pero a pesar de ello, el acercamiento entre estudiantes y obreros artesanos significó un cambio decisivo dentro de las relaciones urbanas. Esto está relacionado con la aparición de una retórica política obrera como resultado del incremento del número de trabajadores industriales y de la dramática subida de precios en el mercado urbano en 1917. Hacia 1920, fecha en que se reúne el congreso nacional de la Federación de Estudiantes del Perú en el Cusco, ya existían diversos grupos obreros (ferrocarril, construcción e industria textil) que apuntaban hacia la constitución de una fuerza laboral independiente, y por eso buscaron nuevos aliados políticos. La reorientación obrera se vinculaba al creciente descontento frente al capitalismo en expansión del proyecto del presidente Augusto B. Leguía, y al mayor acceso informativo a los sucesos de las revoluciones mexicana y rusa que posibilitaba la prensa cusqueña. Pero sobre todo, las rebeliones campesinas hicieron inevitable que los artesanos y trabajadores cusqueños reformularan sus puntos de vista sobre el "problema indígena”, que ya había alcanzado dimensión nacional. La lucha del campo contra la explotación y el abuso forzó a los líderes obreros a reconsiderar las relaciones entre trabajadores urbanos y rurales. Para algunos representantes obreros los campesinos andinos adquirieron el estatus de actores políticos y de posibles aliados en la lucha de clases. La Sociedad de Artesanos estaba escindida en grupos radicalizados y conservadores, situación que explica que en 1924 se fundara con su apoyo la Universidad Popular González Prada, que cedió su local de asambleas para la inauguración en que Luis E. Valcárcel denominó a estudiantes y trabajadores como “camaradas” ("La universidad popular”). Y que después de la acusación de estar alentando un proyecto marxista por parte del obispo católico Pedro P. Farfán, triunfara la facción conservadora de la Sociedad cancelando la cooperación con la Universidad Popular.

\footnotetext{
${ }^{8}$ Como bien lo anota Krüggeler, los artesanos estuvieron sujetos a una serie de construcciones ideológicas y prejuicios raciales que prevalecían no solo en el Cuzco sino en todo el Perú. Los maestros artesanos marcaban su propia distancia social de las clases bajas discriminando a cusqueños que ellos consideraban indios. La etnicidad jugó un rol muy importante en la vida cotidiana de los trabajadores: los maestros artesanos usaban frecuentemente lisuras basadas en prejuicios raciales para insultar a sus empleados, y los trabajadores no dudaban en usar los mismos términos para ofenderse entre ellos. En público el maestro presentaba a su jornalero como un responsable hombre de trabajo, pero en la esfera privada del taller el empleado podría convertirse en un "estúpido indio" si era flojo o no cumplía las expectativas del empleador. Los artesanos y líderes obreros no eran democráticos defensores de principio alguno de igualdad racial. La negativa a vincular las cuestiones de la clase trabajadora con la "cuestión indígena" muestra que muchos líderes obreros representaban más o menos abiertamente los compartidos prejuicios básicos que dominaban la sociedad urbana. Celebrar a los indigenistas cuando hablaban sobre el fabuloso pasado del Perú era apropiado porque demostraba solo una actitud moderna y orientada al futuro. Véase Krüggeler, 180-82.
} 
Todas estas transformaciones sociales y políticas de la sociedad regional del Cusco repercutieron en los discursos culturales y los redimensionaron, a la par que el campo intelectual se diversificó y se establecieron relaciones inéditas. No puede pasar desapercibido que esta reconstitución discursiva es significativa en los textos de Luis E. Valcárcel, quien ya en 1921 propagaba la tesis de la antigüedad inmemorial de la nación en los Andes (“Panorama...”) y proponía un año después, articular la nacionalidad poniendo en comunicación dos temporalidades y movimientos: la velocidad y la arqueología, el avance y el repliegue (“Agua regia”). A principios de la década de 1920 se producirá la ruptura entre la “escuela cusqueña” y el grupo arielista limeño liderado por José de la Riva Agüero, movimiento que encabezó desde el Cusco Valcárcel, quien ya desde el proceso de la reforma de 1909 se había empeñado en acercarse al "problema indígena”, al representar en el Cusco a la Asociación Pro-Indígena que había sido fundada en Lima por Pedro Zulen. Pero se trataba solo de una labor humanitaria y de denuncia de los abusos cometidos por los gamonales con los campesinos indígenas. Pero a comienzos de la década del veinte las categorías de estética, historia y nación habían empezado a madurar en el contexto del debate regional.

El texto “Glosario de la Vida Inkaica” (1922) puede leerse como una ruptura en los esquemas de la historia y la nación, cuando Valcárcel declara la continuidad temporal entre el "Inkario” y los indígenas contemporáneos (3-19), de manera que resquebrajaba la identificación exclusiva de la "gente decente” del Cusco con los incas civilizadores y la desenmascaraba como recurso legitimador de una élite comprometida con los intereses de la propiedad terrateniente. Esto suponía el enfrentamiento con la élite cusqueña y con la población mestiza, que si por un lado cultivaban la admiración hacia los monumentos pre-hispánicos, por otro, practicaban el desprecio cotidiano del campesino andino, conducta que justificaban con una supuesta inferioridad cultural. El “Glosario” se propone a sí mismo como la revelación de una verdad desconocida y como denuncia del "proceso de falseamiento" de la vida incaica hecha por los cronistas españoles. Por primera vez se registra dentro del campo intelectual cusqueño la recusación del discurso incaístaprogresista de los quechuistas cuya fuente principal eran las crónicas coloniales, y el despojo de autoridad a la tradición letrada colonial para trasladarla a nuevos campos disciplinarios desarrollados por las investigaciones arqueológicas, etnográficas, lingüísticas y botánicas. Este traslado se aprecia en el trabajo etnográfico sobre el carácter y evolución de los ayllus realizado por él mismo en su tesis de doctorado en jurisprudencia en San Antonio Abad del Cusco: Del ayllu al imperio, en los cuales cree hallar la resurrección de la vida incaica.

Esta ruptura está estrechamente asociada al viraje que sufre el macro-texto de la cultura peruana, gracias a los estudios sobre la génesis de las culturas andinas promovidas por la arqueología de Julio C. Tello, que a partir de 1919 se definió como una permanente proclama de la autonomía y unidad de la civilización andina. En 1921 Tello publicó Introducción a la historia antigua del Perú en donde desarrolla la teoría del autoctonismo de las culturas andinas, para presentar al hombre antiguo peruano como creador de su propia historia, en estrecha vinculación con el ambiente natural. Para explicar los mecanismos por los cuales el hombre logró dominar a la naturaleza y construir una civilización en los Andes, relaja las diferenciaciones geográficas y culturales, y se aboca 
a demostrar los fundamentos indígenas de la unidad nacional que estaría basada en una unidad geo-étnica, étnica, cultural, lingüística y religiosa. El cataclismo que produjo la conquista europea destruyó los fundamentos de la nacionalidad, porque, según Tello, determinó el abandono de las represas y canales de regadío, la destrucción de las vías de comunicación, el saqueo y derrumbe de los templos, la persecusión religiosa, el olvido de las artes y la esclavización de la población aborigen (47). La historia y conciencia nacional se cubrió entonces de escombros, siendo sustituida por una historia colonial fragmentadora y excluyente.

Por eso, "Panorama de cien años" se cierra con una exhortación a la construcción de la "civilización hispano-peruana” sobre el "pedestal indígena”, cuyos elementos de conjunción debieran buscarse en la adaptación a la naturaleza, la utilización de los propios recursos, el conocimiento de la obra de los antiguos peruanos y la admiración de las generaciones que crearon una civilización en suelo andino. El texto es el llamado del arqueólogo peruano a la generación contemporánea "hacer revivir el pasado”.

Valcárcel se apoyaría en los hallazgos arqueológicos recientes y en las conclusiones de Tello para desarrollar la tesis del agrarismo y de la originalidad de la cultura peruana antigua, que a su vez parte de inhabilitar la oposición ciudad/campo entendida como civilizado/rústico. Este recurso discursivo incluye la presentación de otra civilización: la civilización en el Perú es una creación campesina cuyo fundamento es la sociabilidad cósmica, es decir el estrecho vínculo entre el hombre y el medio ambiente. Los incas, pertenecientes a las “comunidades de labriegos”, se transforman a los ojos de Valcárcel en el pueblo escogido para el renacimiento de la "antiquísima raza keswa” desaparecida durante largas edades, para atribuirles la fundación del Tawantinsuyo como "una sociedad modelo de comunismo". Los incas fueron civilizados y civilizadores porque dominaron la naturaleza, lograron el bienestar social e integraron los “agregados disímiles” dentro del arquetipo de la cultura agraria. Para el autor, los incas construyeron una sociedad comunista sobre la base del colectivismo agrario, la cooperación y la solidaridad; una sociedad en la cual el individuo adquiría valor en tanto constituyente de "guarismo" dentro de una comunidad. ${ }^{9}$

\footnotetext{
${ }^{9}$ Así relata Valcárcel el comunismo incaico en 1922: "El producto arrancado a la tierra con el trabajo de todos no podía ser de nadie en particular. No hay propiedad individual. La tierra pertenece a la asociación. Sin embargo, el individuo está obligado a dos clases de trabajo agrícola; tiene que labrar las parcelas que se le adjudican por el Estado periódicamente y los terrenos privilegiados del Sol y del Inka; en uno y otro esfuerzo cooperan sus cófrades. Cada uno, a más de agricultor, es alfarero, tejedor, fabricante de herramientas o armas. Pero, todos los productos de arte o de la industria se recogen en los depósitos públicos, en kolkas y pirwas, para ser distribuídos 'a cada uno según sus necesidades'. Todos los hombres ejercen una función, dentro de la unanimidad del trabajo. Nadie está exceptuado de aplicar su actividad a la producción: mujeres, niños, ancianos, realizan un género de labor proporcional a sus capacidades. El Inka inicia el laboreo de los campos. No se conoce parasitismo, como tampoco proletariado. La comunidad agraria que hallaron los Inkas recibió de ellos elevada organización que la condujo a su perfeccionamiento. El Tawantinsuyu consumó la utopía de extender el bienestar al mayor número, suprimiendo las desigualdades de la riqueza” (“Glosario..." 95-96).
} 
A la "sociabilidad cósmica” del comunismo andino se añade la ausencia de trascendentalismo alguno, con cuya afirmación Valcárcel desarrolla otra oposición entre el "hombre tawantinsuyu" y el "hombre europeo": el primero, poseedor de seguridad y alegría vital que desconoce al diablo y al infierno, frente al segundo, temeroso de las sanciones en el mundo del más allá o de "Ultratumba" (99). El arraigo del hombre andino a la tierra, el culto hélico y el sentido hedonístico de la vida suscitó en la imaginación del escritor cusqueño la evocación del mundo rural feliz de las églogas virgilianas.

Todo este desarrollo discursivo del "Glosario" apunta hacia la deconstrucción del supuesto carácter primitivo y semi-bárbaro atribuído a la sociedad andina por la cultura oligárquica. Por tratarse de una cultura que responde al medio geo-étnico, nuestro autor la sitúa como ajena a los procesos de imitación internacional, típicos de la cultura criolla. Lo que ésta observa como primitivo no es sino una eliminación voluntaria de lo aleatorio para lograr una elaborada estilización de la propia vida. El texto alcanza su cumbre narrativa después de la reversión de la categoría “primitivo” mediante el desplazamiento semántico en ésta de la capacidad de abstracción y estilización, vaciando de significado la identidad primitivo-atrasado, elaborada por la élite criolla para definir y excluir a la sociedad andina del proyecto nacional. Así elabora la reversión del primitivismo:

Pocos diestros sociólogos han hallado en la simplicidad inkaica argumentos en contra: basta, rudimentaria o incipiente resulta ser la cultura peruana precolombina. Carece de complejidades, no tiene refinamientos, su colectivismo anula libertad y originalidad: de cuántas más la acusan.

Sin embargo, simplicidad no es primitivismo, suele ser estilización. Sencillez de vuelta, supresión consciente de lo superfluo. Tal sucede con el arte decorativo de la cultura inkaica; no tiene parangón en la estudiada sencillez de sus motivos.

La vida inkaica tampoco tiene comparanza en la estudiada sencillez de sus costumbres. Cuánto dominio instrumental y estético para llegar a la suprema elegancia de la simplicidad, cuánto refinamiento espiritual para excluír lo postizo y amanerado. (107, énfasis mío)

Esta discursividad lo llevó a autojustificarse como autoridad enjuiciadora de la modernidad occidental, aquélla de la cual creía haberse apropiado la élite criolla, al escenificar su propio desengaño y el fracaso del proyecto liberal al cual había adherido en la década de 1910. Después de los sucesos de la Primera Guerra Mundial el imaginario de Valcárcel se enfrentó a la disolución del paradigma modernizador en el área andina, para proclamar la inminencia del resurgimiento andino y con ello, la recuperacióninvención de la nación peruana. Aunque dentro de su narración legendaria-histórica, el autor niega explícitamente la posibilidad del retorno al antiguo agrarismo, señala que la creación de la nación supone recuperar los principios vitales andinos que propone como medios de reversión de la herencia colonial. Las afirmaciones constantes de la necesidad reconstructora niegan en parte esta declaración explícita, ya que el agrarismo como solución reversiva, evoca la recuperación de un paraíso perdido. Bajo esta perspectiva, las ciudades se convierten en la encarnación de una "falsa democracia urbana", de la cual además sabe que forma parte en su calidad de intelectual. Nos encontramos pues frente a un impasse entre el carácter urbano del intelectual y de la herencia letrada y el dominio 
sobre el sujeto de una sensibilidad rural que contradice el impulso modernizador hegemónico, pero sobre todo frente al impasse con la fuente de la escritura alfabética. Es esta encrucijada la que dramatiza el cierre del “Glosario" para anunciar la contramodernidad. ${ }^{10}$

Este desarrollo textual de Valcárcel está involucrado con el quiebre en 1923 del apoyo que los sectores medios y populares urbanos le habían dado al presidente Leguía ${ }^{11}$ a raíz de su política indigenista (la nueva constitución política había reconocido a las comunidades indígenas y legalizado el régimen de propiedad comunal), porque reconocerían en ella la estrategia oficial para fortalecer el Estado central. Además de ello, muchos ya se habían desencantado del proyecto capitalista liberal. Una señal de ello fue el discurso de Luis Velazco Aragón pronunciado en el atrio de la catedral del Cusco (22 de abril de 1923), en el que se opuso a la tentativa reeleccionista de Leguía, despotricó contra jueces, legisladores y militares, denunció la falsedad de los cien años de república independiente así como el imperialismo norteamericano, para finalmente incitar a la revolución:

En el Perú necesitamos una renovación completa. A todos los males que he analizado el único remedio es la revolución social como en México. En México como en el Perú ese partido lo forma el limeñismo oligárquico, antro corrupto de políticos, i sus aliados naturales, los terratenientes de provincia y los caciques departamentales. ("La verdad ..." 22-23)

\footnotetext{
10 “Agrarismo: síntesis panteísta que es el valor y la significación de la vida inkaica; del mismo modo que la vida griega, es síntesis artístico-plástica de la existencia humana y el alma cristiana es síntesis suprema de lo ético-religioso. AGRARISMO debe ser nuestra divisa. Solo volviendo a la tierra, podemos purificarnos de los vicios de nuestra falsa democracia urbana. Nuestras ciudades no han nacido espontáneamente, por un movimiento de concentración, sino que fueron fundadas por las necesidades de defender la rapiña de los destructores del Inkanato. Surgían en torno de la fortaleza o del obraje o de la mina, grilletes, peñones de Sísifo de la Raza.Volvamos a la tierra, cultivándola con el mismo fervor que nuestros viejos abuelos los Inkas.La sencillez campesina nos devolverá la confianza y la alegría de la vida que hemos perdido por nuestra desatentada imitación servil de lo extranjero. Rieguen nuestro huerto espiritual las tonificantes linfas andinas, no las aguas pútridas de la moribunda civilización europea” (110-11). El programa del resurgimiento concentra los siguientes valores: el amor a la tierra, la solidaridad y el interés social, la sencillez, la disciplina, el “dinamismo volitivo”, el trabajo, "el principio de la función como determinante del valor del individuo”. Quiero remarcar que la recusación de la función del letrado ocupa una posición importante en tal programa cuando menciona la necesidad de una "parquedad intelectualista".

${ }^{11}$ Con la llegada al poder de Augusto B. Leguía en 1919 culminaba con éxito la lucha por la jornada de ocho horas que se había iniciado en 1912 en Lima con la marcha del "pan grande” en apoyo popular a la candidatura de Billinghurst, y una serie de movilizaciones populares ("paro de las subsistencias”). De esta época data el inicio de la alianza entre los estudiantes universitarios, la pequeña burguesía urbana y el sector obrero, la cual favoreció el Congreso de la Federación de Estudiantes Peruanos realizado en el Cusco en 1920, en el que se sancionó la creación de las Universidades Populares González Prada en toda la república.
} 
La revista Kosko ${ }^{12}$ aglutinó las voces más representativas del movimiento antileguiísta cusqueño iniciado en 1923, y se asumió como vocero y defensor de la recién creada Universidad Popular González Prada (10 de mayo de 1924) en el local de la Sociedad de Artesanos, bajo los postulados de la “educación popular” y “justicia social”; ocupando así dentro de la sociedad el espacio de enfrentamiento a la influencia de la iglesia católica. Después de la clausura de la Universidad Popular, ${ }^{13}$ Kosko fortaleció sus lazos con los sectores populares del Cusco, acentuó su anticlericalismo, empezó a difundir textos de Lenin, Henri Barbusse, Romain Rolland, Vasconcelos y a hacer propaganda del éxito de las revoluciones mexicana y rusa. La revista promovió una candidatura obrera al parlamento, propuso la creación de organizaciones populares independientes y promovió la alianza de los intelectuales cusqueños con el sector obrero. Por otro lado, se enfrentó al regionalismo terrateniente y procuró construir otro regionalismo sustentado en la reforma agraria, el desarrollo industrial, la protección comercial, la solidaridad regional y la creación de un arte con raíces históricas surandinas. Kosko, que aparece en el campo intelectual desligada de intereses académicos, y que fue fundada por el tipógrafo y dirigente sindical Roberto Latorre, estuvo patrocinada por un sector de la pequeña burguesía provinciana, afectada directamente por las transformaciones en la estructura económica del Cusco (la expansión del latifundismo). Se trataba del nuevo estrato urbano que tenía una estrecha relación con el campo porque sus integrantes procedían de familias campesinas, de pequeños comerciantes o de propietarios arruinados de pueblos de la región. Es por ello que logró atraer la colaboración de periodistas, maestros, catedráticos progresistas, estudiantes universitarios radicales, poetas y artistas como Luis E. Valcárcel, Uriel García, Rafael Tupayachi, Ángel Vega Enríquez, José Carlos Mariátegui y Haya de la Torre.

El antileguiísmo que se asentó en el Cusco a partir de Kosko se expresó como antilimeñismo, anticentralismo y federalismo. El descontento de la naciente burguesía agraria, industrial y profesional se organizó en la Logia Federalista (1922-1925), ${ }^{14}$ que fue una organización secreta de oposición a Leguía y conectada con exiliados peruanos en el extranjero. La Logia postulaba el Estado Federal Cusqueño (que comprendería de Arequipa a Ayacucho), en clara referencia al proyecto fracasado del Estado Sud Peruano

\footnotetext{
${ }^{12}$ La revista Kosko tuvo tres etapas: la primera (19 mayo 1924-22 julio 1924) estuvo dirigida por el periodista Luis Yábar Palacio; la segunda (7 agosto 1924-15 abril 1925), por el abogado Luis Felipe Paredes, vinculado al Centro Nacional de Arte y e Historia y al grupo Resurgimiento; y la tercera (hasta el 1 de enero de 1926), por el tipógrafo propietario Roberto Latorre.

${ }^{13}$ La Universidad solo duraría cuatro meses, hasta agosto de 1924, fecha en que por presión de la iglesia sería clausurada por las autoridades acusada de centro de conspiración política. A ello se sumaría el inicio de la represión gubernamental contra el movimiento obrero y estudiantil, que emprendió una campaña antileguiísta en abierta oposición a la convocatoria a elecciones en 1924 por Leguía, la cual perseguía legitimar una reelección fraguada.

${ }^{14}$ Miembros de la Logia eran David Samanez Ocampo, Francisco Tamayo, Luis Yábar Palacio, Roberto Latorre, Víctor Guevara, Alberto Delgado, Rafael Aguilar, Atilio Sivirichi y Abel Montes, entre otros. En setiembre de 1924 la Logia emprende la lucha armada con el propósito de derrocar a Leguía mediante las montoneras de Tamayo y Luis Yábar que tomaron Urubamba y Paucartambo respectivamente. Sin embargo fueron derrotados en octubre del mismo año, con lo que culminan las montoneras en el Perú republicano (Tamayo 33 y 71).
} 
durante la Confederación Peruano-Boliviana en el siglo xIx. Cuando se analiza el regionalismo difundido desde Kosko, que era vocero de la Logia, deben entenderse las implicancias de esta ambición federalista:

Salimos a la lucha periodística con una orientación fija, una senda clara i una convicción firme: defender los intereses de la Sierra i difundir el conocimiento de sus valores hasta hoy olvidados con imperdonable justicia. (I/1, 19 abril 1924)

La prisión de que fue víctima nuestro Director ha dado margen a una serie de comentarios de diversa índole; se creyó que Kosko dejaría de ver la luz pública antes las actitudes de fuerza; muy lejos de eso, nuestra campaña regionalista, sincera, franca i altiva, no puede silenciarse ni permitir que se consumen inauditos atropellos contra la libertad de pensamiento, la de imprenta, i el derecho de libre expresión [... ] i un sagrado derecho nos asiste a reclamar para el Cusco las ventajas que con justicia anhela; la Federación, como un imperativo de vida i un credo de acción: la Libertad como un principio efectivo i tangible. [...]

La Federación salve al Perú! (I/5, 7 julio 1924)

Este innovado regionalismo se sirve de la legitimación de Manuel González Prada, cuyos textos divulgó Kosko, para enfrentar al leguiísmo y así descalificar al centralismo limeño, oponiendo dos regiones, dos ciudades y dos tradiciones históricas: lo colonial y limeño frente a los incaico y serrano, para atribuir al Cusco la hegemonía cultural con implicancias políticas dentro de una nación moderna andina. Como lo expone Federico More:

Y aunque desde aquel año de 1535 en que don Francisco Pizarro rectifica lo hecho por Manco Capahg, Lima es, ostensiblemente, la capital del Perú, Cuzco sigue manteniendo, dentro del alma de la raza, su categoría de pueblo director, de región influyente. La lucha política del Cuzco contra Lima, se llama Regionalismo. Ya el hecho de elevar y mantener la capital colonista en el centro de una zona árida, de un arenal ingalvanizable, reveló el sentido íntimo de esta capitalía: el propósito originario de vivir a costa del resto del país. Fue la subconciencia del centralismo. Hoy, eso se hace concientemente. [...] Junto al Cuzco, condensador multisecular de la Tradición, [...] está el altiplano andino, granja y dehesa de la república y depósito de la leyenda embellecedora de la cultura nacional [...] Más allá del altiplano, está Arequipa, el oasis nervioso, sede de la revolución equilibradora, receptor altoparlante de los anhelos del Incaismo. (“De un ensayo”)

En este cruce cultural y político de intereses y subjetividades que responde al inicio de una nueva era política y económica en el Perú, a la complejización de la sociedad cusqueña y a la emergencia de nuevos sujetos, es que se ubica la disputa de hegemonías y la recartografía cultural peruana realizada en el Cusco por Kosko y otras revistas como La Sierra (Cuzco), Vikuña, Liwi, Más Allá. Ahora la revista Kosko se opone, por ejemplo, a la construcción de un monumento a Túpac Amaru en la "muy virreynal i colonial” Lima, a la que desautoriza apropiarse de un "héroe" andino, porque el Perú no es todavía una nación sino un enclave colonial. Así lo expone Velazco Aragón, quien incita a construir un regionalismo que siente las bases de la nación y confluya con una revolución autóctona: 
Es demasiado el felino de los Andes (Túpac Amaru), para usufructuar un sitio en la ciudad de los virreyes. Ya me figuro la cólera que sentiría el indio formidable, viendo todos los días ese desfile de entalladitos amujerados, capaces de hacerle versos a una zapatilla. Los monumentos deben, según mi concepto, ser erigidos como una realidad de la época a sus precursores [...] Deben responder a una corriente de sinceridad colectiva. Un Túpac Amaru en Lima, sería como erigir un Lenin en Nueva York. [...] El indio rebelde en el seno del colonialismo corruptor i aliado del gamonalismo serrano, sería Túpac Amaru en Lima. [...] En justicia hai que confesar que Túpac Amaru, como verdadero símbolo de revolución aborigen, es tan extraño en el Cuzco como en Lima. Nuestro serranismo no debe ir tan lejos de atribuirse todas las virtudes i ninguno de los defectos. Si estamos como estamos, sin poder exigir en cien años un monumento a ninguno de nuestros grandes hombres regionales es por culpa nuestra .[... Llamamos Atahuallpa a un indio piel roja que en traje de colorado de las praderas del oeste de Estados Unidos está sobre una pila. [...] Nuestro serranismo como tal debe de inspirarse en el símbolo trascendental de Túpac Amaru, que demandando justicia muere rebelde en la demanda, antes que ser servil cortesano o palaciego (“Sobre Túpac Amaru”).

Kosko jugó un papel aglutinante en el sur andino ${ }^{15}$ y logró la convocatoria del trabajo periodístico plural mediante una alianza entre intelectuales y estudiantes cusqueños con los obreros y artesanos de la ciudad, redimensionando el regionalismo académico de la Revista Universitaria, que paulatinamente derivó hacia un posicionamiento político. ${ }^{16}$ Esto se expresó también en el arte gráfico ya que por primera vez salía una revista con diseño, xilografías y fotograbados de temas nativistas. Pero sería con la fundación del grupo Resurgimiento ${ }^{17}$ en 1926, que se intentaría por primera vez la constitución de un frente nacional "indigenista” encargado de denunciar y quebrar el sistema latifundista. Ya se había superado la mera proclama humanitarista y de la reivindicación legalista que había caracterizado a los esfuerzos "indigenistas" anteriores. Ahora se trataba de propiciar la coordinación entre los sectores urbanos (medio y popular) y el sector campesino, y de lograr una organización sólida a nivel nacional. La edición de un boletín de denuncia, "La

\footnotetext{
${ }^{15}$ Kosko logró integrar a colaboradores de Puno, Arequipa, Lima y sobre todo, ya en enero de 1925 circulaba en todo el sur andino incluida Bolivia y Argentina, donde además tenía sus representantes. Gracias a la revista alcanzarán gran difusión en el altiplano las ideas de Luis E. Valcárcel, como lo anota Manuel Quiroga: "por sus grandes sugerencias para tener el hondo amor a la vida agraria, propulsando su desarrollo a base de los sagrados acervos históricos de la raza autóctona”. Kosko 63 (30 dic.1925).

${ }^{16}$ La revista fue censurada y clausurada en 1925, después de trece meses de su fundación. Al igual que en el caso de la Universidad Popular González Prada, sus miembros sufrieron la persecusión política. La integraban periodistas, abogados progresistas, artistas y estudiantes.

${ }^{17}$ El grupo Resurgimiento se fundó el 26 de noviembre de 1926 gracias a la iniciativa de Luis E. Valcárcel, y estuvo integrado por periodistas, abogados progresistas, artistas y estudiantes como Luis Felipe Aguilar, Uriel García, Félix Cosio, Casiano Rado, Roberto Latorre y Luis Felipe Paredes. Nació a raíz de una rebelión de los campesinos de la hacienda de Lauramarca en enero de 1927, quienes se negaron a pagar el derecho de yerbaje y por ello sufrieron la persecución, tortura y exilio forzado en la selva de Cosñipata. Los campesinos que lograron escapar al Cusco tomaron contacto con algunos intelectuales de la ciudad, los que organizaron asambleas en las que aquellos exponían y discutían libremente en quechua sus problemas.
} 
violenta situación de los indios del Departamento”, en que registraron los relatos de los campesinos, difundido en el Cusco y en Lima a través de Amauta, causó la inmediata persecusión de los miembros de Resurgimiento y la disolución del grupo en mayo de 1927, cuando estaba aún en su fase de formación, sin llegar a constituir una institución orgánica ni a fundar una publicación periódica. Y aunque de sus estatutos (Amauta 5, enero 1927) se desprende una orientación paternalista en la que predominan juicios morales y propuestas asistencialistas, y una respuesta de tranformación en términos culturales como la promoción de conferencias en quechua y el estímulo de las manifestaciones del arte popular, es cierto también que anuncia la posibilidad de un gran levantamiento campesino, lo cual significó otorgar proyecciones políticas a un insólito frente nacional.

La revista Kuntur, que tuvo como precedente la fundación de la célula aprista cusqueña (febrero de 1927) y la huelga estudiantil universitaria (mayo de 1927) liderada por el grupo Ande, ${ }^{18}$ se fundó (octubre de 1927) con el objetivo de denunciar y desenmascarar el seudoindigenismo leguiísta, el racismo de la revista La Sierra editada en Lima y la posición de los catedráticos que habían limitado su acción a la actividad académica. Kuntur persiguió la radicalización de los estudiantes e intelectuales "indigenistas", la alianza de obreros y campesinos con el estudiantado radical, el esclarecimiento de la naturaleza económica-política del proceso de constitución de la nación peruana y de la importancia del problema agrario, así como el rechazo de las visiones idealizadas del pasado. El programa básico consistía en la lucha contra el gamonalismo, la eliminación de los latifundios, y la creación del sovietismo agrario como forma política (Francke Ballve 155). Dentro de este contexto disentirían de José Carlos Mariátegui en la formación de un frente cultural amplio y democrático, y criticarían como pasadista la visión cíclica de Luis E. Valcárcel en Tempestad en los Andes. En 1928 el grupo de Kuntur abandonaría el Apra y fundaría la Célula Comunista del Cusco, y a diferencia de los otros grupos, sus actividades se prolongarían aún después que se cancelara la edición de la revista.

Pero todo este programa de acción estaba tejido por la problematización de la construcción de la nación, que ya tenía dieciocho años de desarrollo desde la Reforma de 1909, y por una narración que se orientaba en las coordenadas anticlerical, antiacadémica, antilimeña y antigamonal. Esta narración comprendería la diagnosis del país: ser un espacio muerto para el exterior, ser un espacio colonial donde se concretizó la ruptura de la tradición nacional, y contener en el espacio andino el recinto donde sobrevive esta tradición, que no es otra que la incaica. El Perú es:

Tierra de prodijios muertos, de difuntas maravillas, de olvidos palpitantes; tierra de glorias que siempre fueron i que nunca serán ni nunca son. Tierra de recuerdos frustrados, de memorias a medias, de remembranzas incompletas. Rompió los músculos nobles de su tradición, mutiló las gracias augustas del Imperio i entregóse ignorante i frenética a la lascivia colonial [...] Bajo aquellos montes álzanse los caseríos agrícolas, los hogares

\footnotetext{
${ }^{18}$ En 1925 un grupo de estudiantes de la Facultad de Letras de la Universidad San Antonio Abad formó el grupo Ande, dirigido por Román Saavedra, Julio G. Gutiérrez y Oscar Rozas Tersi. El grupo publicó la revista oral Pututu, de la que salieron siete números, pero que contaba con un solo ejemplar manuscrito que era leído en diferentes locales. La revista era de carácter literario y artístico.
} 
tradicionales donde jeneraciones íntegras transcurrieron dando a la tierra sudores prolíficos. Junto a aquellos caseríos casi lejendarios, vive sin mengua la tradición maravillosa de los Incas (More, “Perú”).

A ello se añade la identificación entre hombre y topografía (“el serrano tiene en su espíritu todas las peripecias topográficas de su suelo, cumbres, hondonadas abismos”) de cuya síntesis debería surgir la “nueva raza”, sensualmente, “libre, sin Dios ni Rey”, según Federico More ("Idearium andino"), a la que se le atribuye la virtualidad de construir un "nacionalismo vital" que restaure la armonía cósmica después del cataclismo de la revolución social (Saavedra). Sin embargo la evocación del paraíso incaico no impide a Kuntur divulgar el discurso de un mestizaje positivo: el del "nuevo indio" creado por Uriel García, para quien el pueblo incaico no fue el "Pueblo Feliz", además de calificar de "sueño utópico" la pretensión de volver a ser el hombre del incanato. El "nuevo indio" es el resultado de la conquista española, entendida como fatalidad histórica del siglo xvi que ha diluido el "espíritu incaico", premisa que sustenta la propuesta de un nacionalismo de carácter universalista. Ni incaísmo ni hispanismo, la nación resultaría de una valoración integral de la historia, compleja y en armonía con sus épocas de formación (prehispánica y occidental). La nación por crear no puede erigir a la arqueología en un "ideario popular”, y debe surgir de la intersección entre factores étnicos, geográficos (paisaje), subjetivos y culturales, imaginándola como la virtualidad de una cultura y sociedad original creada por el bárbaro nuevo indio, aún por llegar. Sin embargo, no deja de contener cierta dosis utópica imaginar un amestizamiento armónico como reinauguración temporal, al mismo tiempo que se exige al "indio actual”, que todavía no es el "nuevo indio” y por tanto refractario a la modernización, el abandono de su lengua, de la organización comunitaria y de la ligazón a la tierra. Y es doblemente paradójico que este último factor -la vinculación afectiva a la tierra-es el que convierte al blanco en "nuevo indio”, y al “indio" en un ser antihistórico, aunque con potencialidad de cambio. En última instancia, postula que el "indio actual” está culturalmente en proceso de amestizamiento, en fase transicional hacia el nacimiento del Manco Cápac de la modernidad :

Ante una antropología fisiológica y mecanicista, el indio conserva la pureza de sangre; pero ante una antropología psicológica y vitalista el indio tiene el alma mezclada, amestizada, digamos, ensanchada inmensamente[...] Y esta cultura porvenir será obra del nuevo indio, de ese espíritu ampliado por la compenetración interior de dos almas contrapuestas. Se comprenderá que el nuevo indio no es precisamente el ponguito convertido en señor, ni el chutillo trajeado de hábitos talares, es el sujeto-indio, mestizo, blanco compenetrado del paisaje andino, de la emoción vernácula y a la vez, dilatado por el pensamiento universal. ("El nuevo indio”).

Nuestros indios ya no tienen el mismo espíritu que creo el pucara, el Koricancha, el Apu, que rindió culto al paisaje en torno iluminado de luz solar, al magnífico panorama de la noche. El indio actual es más un valor biológico, una posibilidad espiritual; mera arcilla para una nueva forma de cultura. En cuanto pervive en ciertas modalidades de su historia autóctona -su agrarismo, su colectivismo, su falta de inquietud sobre problemas de ultramundo, su lengua, etcétera, viene siendo un retrasado, un sujeto de estudio arqueológico o motivo de exaltación lírica, un pueblo antihistórico, por tanto. Pero en 
cuanto sale o se liberta de ese estuario sombrío de su pasado que lo sume en mortal quietud y se pone en marcha, ya es otro, es el nuevo indio. (“El Neoindianismo”)

El neoindianismo de Uriel García enfrenta las tesis de Luis E. Valcárcel que a partir de $1925^{19}$ circulan desde Kosko, La Sierra (Cuzco), y con profusión en otras revistas del sur andino, las que sostienen que la sierra es la nacionalidad y anuncian un proyecto mítico andino que se encubre bajo el "nuevo ciclo" de Spengler, pero que expone la utopía regresiva: el agrarismo, la restauración de las antiguas jerarquías andinas, del culto religioso al sol, de la veneración de huacas, de la revitalización de las comunidades, como respuesta al extrañamiento frente a un Estado, una cultura y una lengua no representativas. Este proyecto extendido en Tempestad en los Andes, ${ }^{20}$ elabora una historia en la que confluyen el igualitarismo y el autocratismo, las relaciones igualitarias entre los ayllus autosuficientes y las relaciones subordinadas de éstos con la élite incaica. Por ello el discurso refuerza el carácter pacífico e integrador de los incas durante las conquistas, sabio y paternal, de la élite dirigente, la armonización de los principios de autonomía y centralismo, para poder relajar la realidad del principio monárquico hasta poder hacerlo coincidir con el comunismo, que en los Andes todavía busca su Lenin.

Kuntur, en sus únicos dos números, entretejió discursos en que convergen la invención de la nación peruana con la crítica del regionalismo o federalismo, del andinismo, de las tesis de Valcárcel y, sobre todo, con la problematización de la letra, del letrado y de las instituciones académicas cusqueñas:

Lo postizo y lo ridículo están en los líricos tonantes del Andinismo. El lema de éste es: lucha y amor pasionales. Liberación del centralismo, por urgencia telúrica y vital y creación del espíritu andino con la misma gozosa sensualidad del amor loco, desenfrenado. Eso es lo viril y heroico. "Ellos los indios" diputados y senadores, como latifundistas atávicos no harían sino cebar los rifles y azuzar una traílla de bandoleros para terminar con los indios que sólo reclaman sus vaquitas y sus carneros. [...] ¿Qué hacen los universitarios cuando se realizan matanzas de indios? Como son cuerdos se callan y como viven de la sangría de los indios sonríen hipócritamente (Saavedra "Perú en ojotas”).

Así como en Bolivia, el ilustre y radical Franz Tamayo, latifundista y gamonal, no puede permitir que los indios de la Isla del Sol, aprendan a leer, aquí nuestros intelectuales "radicalistas", “comunistas", "bolcheviques" o "indigenistas", no permiten que ni los sirvientes de sus casas acudan a las escuelas (Latorre).

La radicalidad de Kuntur debe relacionarse con la iniciativa de un grupo de cusqueños y provincianos emigrados a Lima que editarían la revista La Sierra (homónima de la que apareció en 1910 en el Cusco), entre 1927 y 1930. Sus principales impulsores, los hermanos Guillermo y Víctor Guevara (catedrático de Jurisprudencia en San Antonio Abad), tenían origen terrateniente. Aunque la revista publicaría artículos de intelectuales de diferentes tendencias como Hildebrando Castro Pozo, Emilio Romero, Abelardo Solís, Luis E. Valcárcel, Mariátegui, su orientación sería aprista. En los editoriales se aprecia la

${ }^{19}$ Véanse: Valcárcel, “De los Andes...”; “El Perú...”; “Costa y Sierra”.

${ }^{20}$ Véase López Lenci. 
filiación con Manuel González Prada como en diversas revistas andinas, especialmente cuando se atribuye a la división étnica-cultural del Perú la raíz del problema de la nacionalidad. Como bien lo apunta Francke, la asimilación del pensamiento pradiano fue incompleto porque La Sierra reducía la problemática a la ausencia de una cultura nacional integradora de toda la población peruana, sin considerar el perfil socio-económico ya indicado por Prada (109-86). La dirección de la revista se adjudica la representación del núcleo de la intelectualidad serrana, bautizándose como "serranistas” o “andinistas” cuya misión sería la creación de una auténtica cultura nacional. Para ello emplean un agresivo tono regionalista y emprenden una campaña de propaganda personal que se sirve de la difusión del "Indolatinismo” y "Euroamericanismo" de Vasconcelos, Ricardo Rojas y Alfredo Palacios, representantes de pequeñas burguesías antiimperialistas.

La revista asume un criterio paternalista y moralista que les sirve para denominarse a sí mismos como “indios” y al mismo tiempo manifestar el desprecio por el hombre y la cultura campesina andina y reclamar la modernización occidental. Alaban a terratenientes costeños y coinciden con los intelectuales conservadores limeños como José de la Riva Agüero, Víctor Andrés Belaúnde y Alejandro Deustua en el diagnóstico moralista. Víctor Guevara recurre al determinismo biológico para señalar la decadencia del "indígena”, alcohólico y refractario a la higiene, y proponer una solución eugenésica del mejoramiento de la raza, que el grupo de Kuntur calificará de “solución bovina”. Así se expresa Guevara: “...en atención a que el temperamento de la raza es servil, apático, holgazán, supersticioso, retardatario, conviene cruzarla con los pueblos de las razas europeas dotadas de las cualidades contrarias a esos defectos, capaces de producir un equilibrio progresivo” (8).

La respuesta al problema agrario coincide con el Programa Mínimo del Apra de 1931, según el cual se proponía modernizar y tecnificar la agricultura, repartir las tierras no utilizadas por los latifundios, cooperativizar las comunidades indígenas y fomentar la pequeña propiedad (Wise 167, Francke Ballve 150). Como consecuencia de la ruptura entre Mariátegui y Haya de la Torre, La Sierra iniciaría una campaña de desprestigio del primero, sin embargo, no puede oponerse radicalmente la edición de La Sierra a la revista Amauta, porque intelectuales regionalistas como Valcárcel y Emilio Romero colaboraron en ambas. Además de ello, La Sierra publicó en su número 29 (1929) la respuesta de Mariátegui a un cuestionario preparado por un "Seminario de Cultura Peruana” sobre el problema agrario nacional. Pero como lo apunta Wise (168), la diferenciación entre Amauta o Kuntur y La Sierra se daría por el rechazo categórico que la revista de los cusqueños emigrados harían del socialismo (lo que explica su opción por el aprismo), por su antilimeñismo agresivo y por la salida pedagógica como única solución de la nacionalidad, ${ }^{21}$ mientras Amauta inscribiría como decisivo el rol del campesinado en la construcción del socialismo en el Perú. A pesar de ello, la publicación en Lima de La

\footnotetext{
${ }^{21}$ Según el autor, una revisión de los culture heroes es significativa: en Amauta son los líderes de las revolución rusa (Lenin,Trotski, Lunatcharski), y en La Sierra, son intelectuales latinoamericanos que propagan un americanismo antiimperialista (Manuel Ugarte, Franz Tamayo, Ricardo Rojas, Alfredo L. Palacios y Víctor Raúl Haya de la Torre); y las coincidencias entre las dos publicaciones no dejan de ser interesantes: José Vasconcelos, Henri Barbusse y Sandino.
} 
Sierra, ${ }^{22}$ quiebra el aislamiento cusqueño y surandino del debate sobre la nación y es síntoma de la expansión nacional de las relaciones entre etnicidad y clase, de las pulsiones y subjetividades histórico-estéticas no siempre racionalizadas que se elaboraron a partir de 1909. Para el Cusco se conquistó la categoría de ciudad sagrada de la nación moderna peruana, una cartografía restaurada en su continuidad de memorias antiguas.

Bibliografía

Aguilar, Luis Felipe. Cuestiones Indígenas. Cusco, 1922.

Arenas, Francisco. Colonato de la Raza Indígena. Tesis. Universidad Nacional de San Agustín de Arequipa, 1922.

Bhabha, Homi K. (ed). Nation and Narration. [1990]. London; New York: Routledge, 1999.

Cornejo-Polar, Antonio. Escribir en el aire. Lima: Horizonte, 1994.

Cosio, Félix ."La misión social de la Universidad del Cuzco". Revista Universitaria 36 (1922).

"La Universidad del Cuzco frente al problema indígena”. Revista Universitaria 35 (1921).

Francke Ballve, Marfil. “El movimiento indigenista en el Cuzco (1910-1930)”. Indigenismo, clases sociales y problema nacional. Lima: Celat, 1978.

García, Uriel. “El nuevo indio”. Kuntur 1 (1927). "El Neoindianismo”. Kuntur 2 (1928).

Giesecke, Alberto. “Estudio económico del departamento del Cusco”. Revista Universitaria 3 (1912).

Guevara, Guillermo. “Un año de acción”. La Sierra 13-14 (Lima, 1928).

Guevara, Víctor J. “El problema del indio”. La Sierra 2 (Lima, 1927).

Kapsoli, Wilfredo. Los movimientos campesinos en el Perú. Lima : Delva, 1977

Krüggeler, Thomas. "Indians, workers and the arrival of modernity: Cuzco, Peru, 18951924”. The Americas. A Quarterly Review of Interamerican Cultural History 56/2 (West Bethesda, MD, 1999).

“La violenta situación de los indios del Departamento”. Cusco: Tipografía Renacimiento, 1927.

Latorre, Roberto. “Un artículo de Tristán Maroff”. Kuntur 2 (1928).

López Lenci, Yazmín. El laboratorio de vanguardia literaria en el Perú: trayectoria de una génesis a través de la revistas culturales de los años veinte.. Lima: Horizonte, 1999.

Miró Quesada, Luis. “Diario de los Debates de la Cámara de Diputados” (Lima, 1909). More, Federico. “De un ensayo acerca de la literaturas del Perú”. Kosko 33 (1925).

22 “Kosko será siempre, hoy y mañana, centro, eje y fuente de unidad nacional. Sin tradición, sin sentido histórico de la vida de los pueblos, en suma, sin cultura, no se concibe la nacionalidad. Cuzco significa esto y algo más. En la actualidad representa el meridiano intelectual del Perú. Del Cuzco surgen las más avanzadas ideas de renovación jurídica-política; fuertes espíritus artísticos, hombres que tiene por meta la transformación integral del Perú, en pueblo y hombres libres y nuevos” (Guevara, Guillermo). 
“Perú”. Kuntur 2 (1928).

"Idearium andino”. Kuntur 1 (1927).

Rénique, José Luis. “El Centro Científico del Cuzco (1897-1907)”. Histórica IV/1 (Lima, 1980): 41-52.

“De la fe en el progreso al mito andino: los intelectuales cusqueños”. Márgenes I/ 1 (Lima, 1987).

Saavedra, Román . Presentación a "Nuestros Indios” de Manuel González Prada. Kuntur 1 (1927).

“Perú en ojotas”. Kuntur 1 (1927).

Said, Edward. Culture and Imperialism. New York: Knopf, 1993.

Tamayo Herrera, José. El Cusco del Oncenio.Un ensayo de historia regional a través de la fuente de la Revista KOSKO. Cuadernos de Historia VIII (Lima, 1989).

Tello, Julio C. Introducción a la historia antigua del Perú. Lima: Euforión, 1921.

Ugarte, César Antonio.“Las Universidades Menores”. Revista Universitaria 21 (1917). Valcárcel, Luis E. Tempestad en los Andes. Lima: Amauta, 1927.

"La cuestión agraria en el Cusco". Revista Universitaria 9 (1914).

"Panorama de cien años". La Sierra 8 (Cusco, 1921).

“Agua Regia”. Más Allá 2 (1922).

“Glosario de la Vida Inkaik”. Revista Universitaria 39 (1922).

“De los Andes irradiará otra vez la cultura”. Kosko 50 (1925).

“El Perú, pueblo de indios”. Kosko 47 (1925).

“Costa y Sierra”. La Sierra XVI (Cusco, setiembre de 1925).

“La universidad popular y la solidaridad estudiantil-obrera”. El Sol 9 (abril 1924).

Velazco Aragón, Luis. "La verdad sobre el fango”. El Cusco del Oncenio. Un ensayo de historia regional a través de la fuente de la Revista KOSKO. José Tamayo Herrera, ed. Cuadernos de Historia VIII (Lima, 1989).

"Sobre Túpac Amaru”. Kosko 18 (1924).

Villarán, Manuel Vicente. "Las profesiones liberales en el Perú ”. Discurso en la Universidad de Lima, 1899.

Williams, Raymond. Marxismo y literatura. [1977]. Barcelona: Península, 1980.

Wise, David. "Indigenismo de izquierda y de derecha: dos planteamientos de los años 1920”. Revista Iberoamericana 127 (Pittsburgh, 1984).

REVISTAS CITADAS

La Sierra (Cusco) 1910 (Primera época)/ 1912-1925 (Segunda época)

Revista Universitaria del Cusco 1912-1940 (Primera época)

Más Allá (Cusco) 1922

Kosko (Cusco) 1924-1925/ 1934

Kuntur (Cusco) 1927-1928

Estudios (Cusco) 1917

Nuestra Historia (Cusco) 1914

Liwi (Cusco) 1928 
Amauta (Lima) 1926-1930

La Sierra (Lima) 1924-1929

Periodicos

El Sol (Cusco)

El Tiempo (Lima)

El Pueblo (Arequipa) 